\title{
Analysis of Canadian Inquiry-based Science Teaching Practices and its Implications for Reciprocal Learning
}

\author{
Geri Salinitri $^{1{ }^{* *}, \text { Stephanie Palazzolo }}{ }^{1}$, Ruxandra Nahaiciuc ${ }^{1}$, Emilia Iacobelli ${ }^{1}$, \\ Yuanrong Li $^{2}$, George Zhou $^{1}$ \\ ${ }^{1}$ Faculty of Education, University of Windsor, Windsor, Canada \\ ${ }^{2}$ Faculty of Chemistry and Chemical Engineering, Southwest University, Chongqing, China
}

Copyright $(2018$ by authors, all rights reserved. Authors agree that this article remains permanently open access under the terms of the Creative Commons Attribution License 4.0 International License

\begin{abstract}
As part of the SSHRC partnership grant on Reciprocal Learning between Ontario, Canada and Southwest, China, we examined the commonalities and differences in secondary school Inquiry-based Teaching (IBT) in science between sister schools in Ontario, Canada and Southwest, China. Canadian and Chinese teachers' interpretations of inquiry through video-recorded lessons, qualitative observational annotations, and quantitative data collected via the EQUIP instrument were analyzed. Results suggest that there is a non-significant difference in application of IBT between secondary science teachers in Ontario, Canada and in Southwest, China between the reciprocal learning populations. Both populations are perceived to use inquiry-based teaching methods in their classrooms proficiently, and that students are more receptive at a higher cognitive level when teachers incorporate IBT.
\end{abstract}

Keywords Inquiry-based Teaching, Comparative Study, Secondary Science Teaching

\section{Introduction}

The Ontario Science curriculum is designed to promote higher level thinking through inquiry-based learning, but the delivery of any curriculum is dependent on the ability of the teacher to teach through inquiry (Sanders \& Rivers, 1996). All teachers should then be teaching through inquiry in order to successfully meet the Ministry approved curricula. Although many teaching methods and instructional strategies exist, inquiry is of main focus for this study because it is one of the core standards of practice that the Ministry of Education supports (Ministry of Education, 2011), and one that our Chinese reciprocal partners are interested in and are implementing as well. The Reciprocal Learning Project is an agreement between the
Greater Essex County District School Board (GECDSB) in Windsor, Ontario, Canada and Southwest University in China. The intent of the project is to share experiences of teaching and learning between the east and the west. Schools in Windsor are designated to be partners with schools in Southwest, China. The schools meet monthly through Skype and have discussions on pedagogy. Many other reform-based initiatives also value inquiry-based instruction as a main component of effective instruction (National Science Education Standards, 1996, 2001; National Council of Teachers of Mathematics, 2000; American Association for the Advancement of Science, 1993, 1998; Bransford, Brown \& Cocking, 2000; Llewellyn, 2002).

Inquiry-based teaching (IBT) is a method that is widely used to improve student achievement in academia (Llewellyn, 2002). Students are more likely to become engaged and self-directed learners in an inquiry-based environment which can lead to increases in student achievement (Jang, Reeve \& Deci, 2010; Paris \& Paris, 2001). Educational institutions have supported IBT and have published models to disseminate the utilization of inquiry-based teaching (National Science Education Standards, 1996, 2001; National Council of Teachers of Mathematics, 2000; American Association for the Advancement of Science, 1993, 1998). The Ministry of Education in Ontario identifies four key elements to teach using an inquiry-based approach: 1. Student engagement and focus, 2. Student communication, explanations, and reflections to share learning, 3. Student exploration and investigation, and 4. Student analysis and extension of thinking (Ministry of Education, 2011). Creating the list of Ministry expectations for IBT was one challenge that took years to create, but it is a whole other realm to execute these expectations while teaching. This study examines the connection of the theory behind IBT and the practice by analyzing the similarities and differences of inquiry-based teaching in Ontario, Canada and Southwest, China. 


\section{Literature Review}

\section{Theoretical Framework}

An international program, called Trends in International Mathematics and Science Study (TIMSS, 2015), assesses grade 4 student performance in science. Science achievement scores in Ontario, Canada dropped significantly from 540 (2003) to 525 (2015), whereas scores in Southwest, China have increased to 555 (2015). This shows that Canadians are lacking something in science education.

The Program for International Student Assessment (PISA, 2015) is another international test that assesses science progress in 15-year-old students. The most recent PISA science results from 2015 (OECD, PISA, 2015) indicate that Ontario, Canada has dropped 2 points to an average of 528 in science, and Southwest, China has maintained their score of 532. These two measures reinforce that Canadians are lacking something in science education that we could learn from our partners in Southwest, China, therefore, furthering the importance of analyzing the teaching methods utilized in Ontario, Canada and Southwest, China.

There are many teaching methods and instructional strategies that have been shown to support student achievements, for instance, teacher self-efficacy (Buss, 2010; Pajares, 2005; Posnanski, 2002; Riggs, 1995; Shrigley and Johnson, 1974), mindset (Blackwell, Trzesniewski, \& Dweck, 2007), and degree earned and years of experience teaching (Giddings, 2005; Howitt, 2007; Nenneman, 1971). This study is conducted in schools where inquiry is a core standard for successful education (Ministry of Education, 2011), thus the focus is the inquiry-based instructional strategy.

"Inquiry is a multifaceted activity that involves making observations; posing questions; examining books and other sources of information to see what is already known; planning investigations; reviewing what is already known in light of experimental evidence; using tools to gather, analyze, and interpret data; proposing answers, explanations and predictions; and communicating the results. Inquiry requires identification of assumptions, use of critical and logical thinking, and consideration of alternative explanations." (National Research Council, 1996, p. 23)

Dewey (1916) believed that teachers should allow student curiosity to guide learning. Teachers who support student curiosity elicit a sense of student empowerment to explore concepts, formulate explanations, and delve into solutions. Dewey noted that teachers who adopt an inquiry-based scientific approach to teaching can improve student learning. Vygotsky (1962) also believed that learning was an active process that incorporated scaffolding, and higher cognitive learning.

Educational research supporting inquiry-based teaching
(IBT) is encouraging instructional institutions to adopt a more engaging, exploratory, and critical-thinking environment for students. IBT is a recurring theme that to be successful in educational instruction in science, school systems are pushing the implementation of IBT (National Science Education Standards, 1996, 2001; National Council of Teachers of Mathematics, 2000; American Association for the Advancement of Science, 1993, 1998). However, it is the quality of inquiry-based teaching that counts (Marshall, Smart \& Horton, 2009). As such, proper training for teachers in the areas of understanding and implementing IBT in secondary science classrooms is critical to its overall success.

Many teachers have a misconception of inquiry-based teaching, where they believe that inquiry-based teaching requires teachers who merely engage students in activities (Moscovici \& Holdlund-Nelson, 1998), whereas others view it as a deep investigation process (Marshall, et al., 2009). This disconnect in teacher comprehension of IBT is still being investigated, and instruments continue to be developed for measuring the effectiveness of IBT.

\section{Studies and Selection of Instrumentation}

IB teaching is widely assessed on the teacher's ability to include open-ended questioning, scaffolding (Vygotsky, 1978), and higher-level thinking (Llewellyn, 2002; Tomlinson \& McTighe, 2003) in his or her lesson. Past studies and their instruments used to model inquiry-based teaching are discussed in this section.

The Reformed Teaching Observation Protocol (RTOP; Sawada, Piburn, Falconer, Turley, Benford \& Bloom, 2000) uses a constructivist approach as more of an evaluative tool for teaching, instead of focusing on solely inquiry-based teaching. The RTOP also utilizes a Likert scale, which makes it difficult to provide reasons for differences between a 4 and 5 on the Likert scale, and leaves little room for pinpointing improvement and reflective feedback for the teachers.

Another instrument that involves inquiry-based teaching is the Science Teacher Inquiry Rubric (STIR; Beerer \& Bodzin, 2003). Bodzin and Beerer (2003) conducted a study that observed ten science teachers for inquiry-based attributes. Results from this pilot study determined the STIR is an unsuccessful self-assessment instrument $(\mathrm{r}=0.58)$, but an effective observational tool $(\mathrm{r}=1)$. This tool evaluates teacher standards for their teaching practice, but it does not provide specific feedback for teacher improvement, nor do its studies show reliability or validity information.

Teacher efficacy scales (Riggs \& Enochs, 1990) are also a popular measure of self-reporting teaching abilities, however, they focus solely on self-efficacy. Although self-efficacy has been studied in conjunction with inquiry-based teaching (Hamzeh, 2014), the need for this study was an instrument that explicitly assessed inquiry. 
Due to a lack of consistency in instruments to assess how science teachers describe, understand, and implement inquiry-based teaching, Marshall, Horton, Igo \& Switzer, (2009) created an instrument to assess inquiry-based teaching. The Electronic Quality of Inquiry Protocol (EQUIP) was developed to measure quantity and quality of inquiry in K-12 science and mathematics classrooms in the United States. EQUIP's parameters are based on whether the teacher's lesson follows a 4Ex2 Instructional Model (Marshall, Horton \& Smart, 2008). A 4Ex2 (“4E by 2") Instructional Model follows a lesson that engages students, allows student exploration, encourages student explanation, and extends lessons in order to support assessment and reflection. This model links conceptual understanding of content with inquiry-learning experiences, and integrates assessment and metacognition through reflection. In order to utilize the EQUIP model, lessons should follow the three united constructs of formative assessment, inquiry instruction, and metacognition (Marshall, Horton \& Smart, 2008). Engagement refers to how involved the students are within the lesson. Exploration is how much of an opportunity is given to students to make a hypothesis or reach a conclusion. Explanation refers to clarifying an action or event. Extension is the art of stretching the lesson beyond the initial stages of explanation and seeing how it relates to other lessons and subjects.

Marshall and Horton (2011) further studied a group of middle school science (12) and mathematics (10) teachers. Teachers were observed for assessment of inquiry-based instruction via the EQUIP instrument. Participant teachers were separated into two groups: those who allowed student exploration before explanation, and those who merely provided students with explanations. Results indicate that when teachers spent more time allowing students to explore, students were participating more frequently and at a higher cognitive level than when teachers spent little time for student exploration. There was a positive correlation between exploration time and cognitive level of students, and a negative correlation between explanation time and cognitive level of students.

This study uses the EQUIP instrument for its thoroughly descriptive assessment questions towards inquiry, for its reliability (16 paired observations, interrater reliability via Cohen's kappa 0.61 for instruction, with a coefficient of determination of $0.856: \mathrm{n}=16, \mathrm{~K}=0.61, \mathrm{r}^{2}=0.856$ ) and validity (internal consistency of $0.858-0.912, \alpha>0.858$ ) values, for its similar standards of inquiry-based lessons to that of Ontario, Canada's model and Southwest, China's model, and for its alignment with this study's definition of inquiry.

\section{Statement of Problem}

The Reciprocal Learning Project (RLP) between Ontario, Canada and Southwest, China has raised much interest in international differences in education. There is a lack of international comparative research of inquiry-based teaching (IBT) in secondary science. Video-analysis of science lessons in both countries allows for a more in-depth observation, analysis, and sharing of strategies.

\section{Purpose and Overview}

This study focuses on identifying the commonalities and differences in secondary IBT in science between Ontario, Canada and Southwest, China. The purpose of this study is to examine secondary school science teachers' comprehension of IB teaching through their lessons.

We examine teachers differing ideas of IB teaching in secondary science. There is no consistent style of teaching that seems to be the most effective, however, as previously stated, the inquiry-based teaching style is supported as a means to successful educational programs. Can we specify details of an inquiry-based teaching approach that consolidates effective learning?

\section{Methodology}

\section{Purpose \& Research Questions}

The purpose of this study is to analyze secondary school science teachers' comprehension of IB teaching through their lessons. The following research questions frame this study:

1. Is IBT in secondary science practiced in Ontario, Canada? How? - The EQUIP instrument is used to collect quantitative and qualitative data regarding IBT. This data will be combined with additional qualitative reflections to provide insight into how IBT is used in secondary science in Ontario, Canada and Southwest, China.

Hypotheses: $\mathrm{H}_{\mathrm{O}}$ - IBT is not practiced in secondary science classrooms in Ontario, Canada.

$\mathrm{H}_{\mathrm{A}^{-}}$IBT is practiced in secondary science classrooms in Ontario, Canada.

2. How effective is IBT in secondary science in Ontario, Canada? - The EQUIP instrument provides a scoring system which rates IBT amongst teacher participants, which when analyzed can provide insight into the effectiveness of IBT based on student engagement.

Hypotheses: $\mathrm{H}_{\mathrm{O}}$ - IBT is not effective in secondary science classrooms in Ontario, Canada.

$\mathrm{H}_{\mathrm{A}^{-}}$IBT is effective in secondary science classrooms in Ontario, Canada.

3. Is IBT in secondary science practiced in Southwest, China? How? - The EQUIP instrument will be used to collect quantitative and qualitative data regarding IBT in Southwest, China. This data will 
be combined with additional qualitative reflections to provide insight into how IBT is used in secondary science in Southwest, China.

Hypotheses: $\mathrm{H}_{\mathrm{O}}$ - IBT is not practiced in secondary science classrooms in Southwest, China.

$\mathrm{H}_{\mathrm{A}^{-}}$IBT is practiced in secondary science classrooms in Southwest, China.

\section{Research Design}

This observation-based video analysis research study follows a mixed-methods research approach to analyze IBT in secondary science. This study uses a mixed-methods research approach because it combines two sets of data to answer one or more questions (Creswell \& Clark, 2007). To answer the research questions, quantitative data using a classroom observation checklist, and qualitative data through observational reporting is triangulated.

\section{Study \& Partic5ipants}

In the fall semester of 2015, six volunteer, contracted, secondary school science teachers from a variety of schools within the Greater Essex County District School Board (GECDSB), participated in the video analysis study. Teacher candidate research assistants arranged observation/video recording dates and locations with each GECDSB science teacher and were consented to video tape each lesson. Videos were recorded on a designated camera to retain participant confidentiality. Lessons were recorded in the teacher's authentic classroom setting, with the teacher's normal group of students. The following Canadian courses were observed and recorded in the video analysis study: SNC1D (Grade 9 Academic Science), SNC2D (Grade 10 Academic Science), SBI3C (Grade 11 College level Biology), SBI3U (Grade 11 University level Biology), SCH3U (Grade 11 University level Chemistry), and SBI4U (Grade 12 University level Biology). Lessons were reviewed and analyzed for specific factors related to inquiry-based teaching, including open-ended questioning, scaffolding, and higher-level thinking. The following Chinese courses were observed and recorded in 2017 in the video analysis study: Chemistry: Grade 10, Chemistry: Grade 11, Biology: Grade 11 (2), Physics: Grade 10 (2), and Physics, Grade 11. Similarly, to the lessons of the Canadian teachers, the lessons of the Chinese teachers were analyzed for factors related to inquiry-based teaching.

\section{Instrumentation}

To analyze the lessons, each teacher candidate researcher provided annotated observational summaries for their respective teacher participant's lesson. These qualitative annotations are triangulated with a quantitative Electronic Quality of Inquiry Protocol (EQUIP).

The qualitative annotations follow the construct of self-report questionnaires (Dinsmore, Alexander \&
Loughlin, 2008). Self-report questionnaires were first utilized in a study regarding self-regulated learning (Cleary, Callan, Malatesta \& Adams, 2015), where a series of statements about beliefs, attitudes, and behaviours generate reflective responses. In the current study, teacher candidate researchers reported detailed observations portraying the teacher participant's IBT. These reflections are used in conjunction with the quantitative data to make inferences about IBT in Canadian schools.

The Electronic Quality of Inquiry Protocol assessment has been developed to measure quantity and quality of inquiry in K-12 science and mathematics classrooms through 19 indicators within four domains: curriculum, instruction, discourse, and assessment (Marshall, Horton \& Smart, 2008). The assessment has 8 sections: i. Descriptive Information, ii. Time Usage Analysis, iii. Lesson Descriptive Details, iv. Instructional Factors, v. Discourse Factors, vi. Assessment Factors, vii. Curriculum Factors, and viii. Summative Overviews (Marshall, Horton \& Smart, 2008). Level of inquiry-based teaching is measured in the four domains aforementioned, following a 4-level scale: 1-Pre-inquiry, 2-Developing inquiry, 3-Proficient inquiry, and 4-Exemplary inquiry. Scores are averaged from the four domains to provide teachers with a comprehensive description of their IBT ability, and it also identifies areas teachers can improve upon. Time analysis reports the exact amount of time that the teacher participant spends on activity facilitation, organization, inquiry instruction, and assessment, and it also reports time the students spend on being attentive, and their time spent on cognition as described in the EQUIP assessment utilization instructions (Marshall, et a., 2008).

\section{Ethics}

The Research Ethics Board approved this study under the umbrella of the Ontario, Canada-Southwest, China Reciprocal Learning Project. Teacher candidate researcher observations and opinions are respected and are portrayed as originally recorded. Student faces were not recorded on video footage in order to maintain student privacy. All GECDSB teacher participant lessons and materials collected remain confidential. Both teacher candidate researchers and GECDSB teacher participant names and information remain confidential, and as informed, participants were able to leave the study at any time.

\section{Data Collection \& Analysis}

The following data presented are collected from observational records based on teacher candidate researchers, and from the EQUIP assessments (section iii is omitted as it is given to teachers for metacognitive reflection as baselines for improvement). Teacher participant names are withheld for confidentiality, instead the codes based on the class they taught replace their name. 
In the case of teacher participants who agreed to the recording of more than one lesson, only the first lesson is recorded in detail in Table 1 or Table 2. Supplementary lesson data is included in the quantitative data analysis in Table 3 and Table 4. Video footage is archived until publication of the paper, upon which it will be deleted.

Table 1. EQUIP scores for Canadian Teachers. Rated on an increasing scale of proficiency in inquiry-based teaching 1(Pre-inquiry) to 4 (Exemplary inquiry).

\begin{tabular}{|c|c|c|c|c|c|c|}
\hline $\begin{array}{c}\text { Teacher } \\
\text { Participant }\end{array}$ & $\begin{array}{c}\text { Descriptive } \\
\text { Information }\end{array}$ & $\begin{array}{c}\text { Instructional } \\
\text { Factors }\end{array}$ & $\begin{array}{c}\text { Discourse } \\
\text { Factors }\end{array}$ & $\begin{array}{c}\text { Assessment } \\
\text { Factors }\end{array}$ & $\begin{array}{c}\text { Curriculum } \\
\text { Factors }\end{array}$ & $\begin{array}{c}\text { Comprehensive } \\
\text { Score }\end{array}$ \\
\hline SNC1D & $\begin{array}{c}\text { Male } \\
26 \text { yrs exp } \\
\text { "Gas Lab" }\end{array}$ & 2 & 2 & 2 & 2 & 2 \\
\hline SNC2D & $\begin{array}{c}\text { Male } \\
26 \text { yrs exp } \\
\text { "Covalent \& Ionic } \\
\text { Bonds" }\end{array}$ & 2 & 2 & 2 & 2 & 2 \\
\hline SBI3C & $\begin{array}{c}\text { Male } \\
10 \text { yrs exp } \\
\text { "Circulatory } \\
\text { System" }\end{array}$ & 3 & 3 & 3 & 3 & 3 \\
\hline SBI3U & $\begin{array}{c}\text { Male } \\
17 \text { yrs exp } \\
\text { "Respiratory } \\
\text { System" }\end{array}$ & 3 & 3 & 2 & 2 & 2 \\
\hline SCH3U & $\begin{array}{c}\text { Female } \\
20 \text { yrs exp } \\
\text { "Stoichiometry \& } \\
\text { Limiting Reagent", }\end{array}$ & 3 & 3 & 3 & 3 & 3 \\
\hline SBI4U & $\begin{array}{c}\text { Male } \\
26 \text { yrs exp } \\
\text { "DNA Replication" }\end{array}$ & 3 & 3 & 3 & 3 & 3 \\
\hline
\end{tabular}

Table 2. EQUIP scores for Chinese Teachers. Rated on an increasing scale of proficiency in inquiry-based teaching 1 (Pre-inquiry) to 4 (Exemplary inquiry).

\begin{tabular}{|c|c|c|c|c|c|c|}
\hline $\begin{array}{c}\text { Teacher } \\
\text { Participant }\end{array}$ & $\begin{array}{l}\text { Descriptive } \\
\text { Information }\end{array}$ & $\begin{array}{c}\text { Instructional } \\
\text { Factors }\end{array}$ & $\begin{array}{c}\text { Discourse } \\
\text { Factors }\end{array}$ & $\begin{array}{c}\text { Assessment } \\
\text { Factors }\end{array}$ & $\begin{array}{c}\text { Curriculum } \\
\text { Factors }\end{array}$ & $\begin{array}{c}\text { Comprehensive } \\
\text { Score }\end{array}$ \\
\hline $\begin{array}{l}\text { Chemistry } \\
\text { Grade } 10\end{array}$ & $\begin{array}{c}\text { Female } \\
16 \text { yrs exp } \\
\text { "Iron Hydroxides" }\end{array}$ & 2 & 3 & 3 & 2 & 3 \\
\hline $\begin{array}{l}\text { Chemistry } \\
\text { Grade } 11\end{array}$ & $\begin{array}{l}\text { Female } \\
10 \text { yrs exp } \\
\text { "Alcohol" }\end{array}$ & 3 & 3 & 3 & 3 & 3 \\
\hline $\begin{array}{c}\text { Biology } \\
\text { Grade } 11\end{array}$ & $\begin{array}{c}\text { Female } \\
16 \text { yrs exp } \\
\text { "The Internal } \\
\text { Living Environment } \\
\text { of Cells" }\end{array}$ & 2 & 1 & 2 & 2 & 2 \\
\hline $\begin{array}{l}\text { Biology } \\
\text { Grade } 11\end{array}$ & $\begin{array}{c}\text { Female } \\
2 \text { yrs exp } \\
\text { "Cancer Cells", }\end{array}$ & 2 & 2 & 3 & 2 & 2 \\
\hline $\begin{array}{l}\text { Physics } \\
\text { Grade } 10\end{array}$ & $\begin{array}{c}\text { Female } \\
1 \text { yrs exp } \\
\text { "Universal } \\
\text { Gravitation and } \\
\text { Spaceflight" }\end{array}$ & 2 & 2 & 2 & 2 & 2 \\
\hline $\begin{array}{l}\text { Physics } \\
\text { Grade } 10\end{array}$ & $\begin{array}{c}\text { Female } \\
17 \text { yrs exp } \\
\text { "The Universal } \\
\text { Gravitation between } \\
\text { the Sun and the } \\
\text { Planets" }\end{array}$ & 4 & 3 & 4 & 3 & 4 \\
\hline $\begin{array}{l}\text { Physics } \\
\text { Grade } 11\end{array}$ & $\begin{array}{c}\text { Male } \\
\text { 20yrs exp } \\
\text { "Physical Quantity } \\
\text { that Describes the } \\
\text { Alternating } \\
\text { Current" }\end{array}$ & 3 & 3 & 3 & 3 & 3 \\
\hline
\end{tabular}




\section{Analysis of Quantitative Data}

To analyze quantitative data from the EQUIP assessment, data from EQUIP sections iv-vii were compiled for observational results. In section ii, time was analyzed for observational results.

Table 3. Group Statistics for EQUIP data comparison of Canada and China

\begin{tabular}{|c|c|c|c|c|c|}
\hline $\begin{array}{c}\text { Group } \\
\text { Statistics }\end{array}$ & & & & & \\
\hline \multirow{2}{*}{$\begin{array}{c}\text { Instructional } \\
\text { Factors }\end{array}$} & Country & $\mathrm{N}$ & Mean & $\begin{array}{c}\text { Std. } \\
\text { Deviation }\end{array}$ & $\begin{array}{c}\text { Std. Error } \\
\text { Mean }\end{array}$ \\
\cline { 2 - 6 } & China & 11 & 2.55 & .688 & .207 \\
\hline \multirow{2}{\text{Discourse}}{\begin{tabular}{c} 
Factors \\
\cline { 2 - 6 }
\end{tabular}} & Canada & 9 & 2.44 & .527 & .176 \\
\hline \multirow{2}{*}{$\begin{array}{c}\text { Assessment } \\
\text { Factors }\end{array}$} & China & 11 & 2.55 & .820 & .247 \\
\cline { 2 - 6 } & China & 11 & 2.91 & .701 & .211 \\
\hline $\begin{array}{c}\text { Curriculum } \\
\text { Factors }\end{array}$ & Canada & 9 & 2.44 & .527 & .176 \\
\cline { 2 - 6 } & China & 11 & 2.45 & .522 & .157 \\
\hline $\begin{array}{c}\text { Comprehensive } \\
\text { Score }\end{array}$ & Canada & 9 & 2.44 & .527 & .176 \\
\cline { 2 - 6 } & China & 11 & 2.73 & .786 & .237 \\
\hline
\end{tabular}

Table 4. Independent Sample Test - t-test for Equality of Means

\begin{tabular}{|c|c|c|c|c|}
\hline \multirow[t]{3}{*}{$\begin{array}{l}\text { Independent } \\
\text { Samples Test } \\
\end{array}$} & & & & \\
\hline & & \multicolumn{2}{|c|}{$\begin{array}{c}\text { Levene's Test for } \\
\text { Equality of Variances }\end{array}$} & $\begin{array}{l}\text { t-test for } \\
\text { Equality of } \\
\text { Means }\end{array}$ \\
\hline & & $\mathrm{F}$ & Sig. & $\mathrm{t}$ \\
\hline \multirow{2}{*}{$\begin{array}{c}\text { Instructional } \\
\text { Factors }\end{array}$} & $\begin{array}{c}\text { Equal } \\
\text { variances } \\
\text { assumed }\end{array}$ & 1.061 & .317 & .036 \\
\hline & $\begin{array}{c}\text { Equal } \\
\text { variances not } \\
\text { assumed } \\
\end{array}$ & & & .037 \\
\hline \multirow{2}{*}{$\begin{array}{l}\text { Discourse } \\
\text { Factors }\end{array}$} & $\begin{array}{c}\text { Equal } \\
\text { variances } \\
\text { assumed }\end{array}$ & 1.769 & .200 & -.319 \\
\hline & $\begin{array}{c}\text { Equal } \\
\text { variances not } \\
\text { assumed } \\
\end{array}$ & & & -.333 \\
\hline \multirow{2}{*}{$\begin{array}{l}\text { Assessment } \\
\text { Factors }\end{array}$} & $\begin{array}{c}\text { Equal } \\
\text { variances } \\
\text { assumed }\end{array}$ & .000 & .990 & -1.642 \\
\hline & $\begin{array}{c}\text { Equal } \\
\text { variances not } \\
\text { assumed } \\
\end{array}$ & & & -1.691 \\
\hline \multirow{2}{*}{$\begin{array}{l}\text { Curriculum } \\
\text { Factors }\end{array}$} & $\begin{array}{c}\text { Equal } \\
\text { variances } \\
\text { assumed }\end{array}$ & .007 & .932 & -.043 \\
\hline & $\begin{array}{c}\text { Equal } \\
\text { variances not } \\
\text { assumed } \\
\end{array}$ & & & -.043 \\
\hline \multirow{2}{*}{$\begin{array}{l}\text { Comprehensiv } \\
\text { e Score }\end{array}$} & $\begin{array}{c}\text { Equal } \\
\text { variances } \\
\text { assumed } \\
\end{array}$ & 1.781 & .199 & -.921 \\
\hline & $\begin{array}{c}\text { Equal } \\
\text { variances not } \\
\text { assumed } \\
\end{array}$ & & & -.959 \\
\hline
\end{tabular}

From the group statistics in Table 3, it can be noted that there were no significant differences in the use of IBT within Canadian Teachers and within Chinese Teachers, nor was there any significant difference between Canadian Teachers and Chinese Teachers. Further confirmation of this statement can be found from the independent sampling test displayed in Table 4.

Using Levene's Test for Equality of Variances, all significance values (p-values) were determined to be greater than 0.05 . Therefore, the sample variances are assumed to be equal. A t-test was conducted, and the results were used to compare the mean EQUIP scores of the samples for each factor between the respective countries. There were only minor differences between each country's means with respect to Instructional Factors and Curriculum Factors. The t-values close to zero show agreement with the null hypothesis for each factor. Differences between the means for Discourse Factors and the Comprehensive Score were greater than the previous two factors, showing a larger deviation from the null hypothesis. The greatest difference between the means was evident in Assessment Factors. The t-test provides evidence that, in terms of assessment, the null hypothesis may not be true due to the major differences between the sample data and the null hypothesis. Ultimately, since a four-point scale was used, in combination with a small sample size for each country, the results are not generalizable.

\section{IBT Comparison Between Ontario, Canada and Southwest, China}

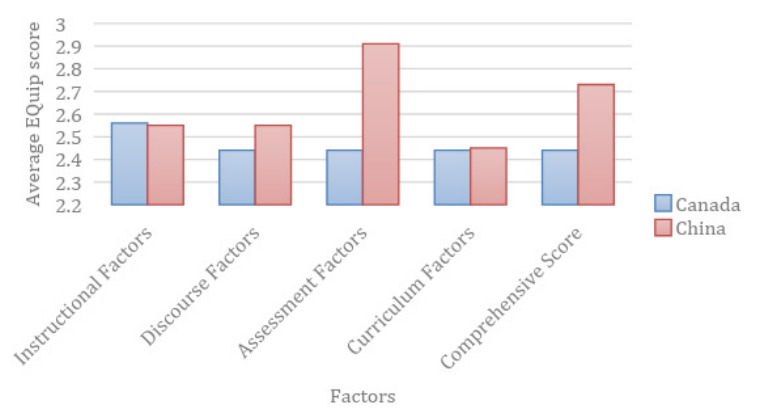

Figure 1. IBT Comparison between Canada and China

\section{Analysis of Qualitative Data}

To analyze the qualitative data from the EQUIP assessment, a cross-case analysis between teacher participants was conducted. Based on the construct of self-regulated reflections (Cleary, Callan, Malatesta \& Adams, 2015; Dinsmore, Alexander \& Loughlin, 2008), teacher participant IBT observations were compared. In this study, reflections were used in conjunction with the EQUIP data to make inferences surrounding IBT. Here we provide a summary of observational reflections, and we highlight themes from the six teacher participant lessons. 
Table 5. Canadian teacher candidate reflections.

\begin{tabular}{|c|c|}
\hline Teacher Participant & Canadian Teacher Candidate Researchers' Reflections \\
\hline SNC1D & $\begin{array}{l}\text { "Labs are not inquiry- or problem-based like I thought. The lab was completely laid out for the students, and all } \\
\text { they had to do was follow the steps." } \\
\text { "The teacher did ask questions, but they weren't much thought provoking." } \\
\text { "I think a more inquiry-based way to present the lab would be to allow the students to combine their own choices } \\
\text { of chemicals." }\end{array}$ \\
\hline SNC2D & $\begin{array}{l}\text { "This was a problem-based lab. Students were given the steps and } 4 \text { compounds and they had to solve the } \\
\text { problem by going through the lab. When students asked questions that related to their notes or the lab, he would } \\
\text { answer with another question to force them to find the answer themselves." } \\
\text { "There was little to no inquiry in this lesson because it was a more structured lab they had to complete rather than } \\
\text { one they got to construct themselves." }\end{array}$ \\
\hline $\mathrm{SBI} 3 \mathrm{C}$ & $\begin{array}{l}\text { "Students responded well to whiteboard review questions. The questions started off easy, and the teacher } \\
\text { provided encouraging comments when they answered." } \\
\text { "Students were extremely engaged and interested because they had control of the exploration of the goldfish." } \\
\text { "Students were beginning to pose some good questions." }\end{array}$ \\
\hline SBI3U & $\begin{array}{l}\text { "The teacher used a lecture-based style, connecting old material with new material." } \\
\text { "He used a lot of visuals and mechanics to demonstrate respiration. He got the students involved by making them } \\
\text { think about their own breathing." } \\
\text { "The teacher used experimental learning, which allowed students to get out of their seat." } \\
\text { "There was no inquiry-based information in his lesson today. There was more problem-based teaching, } \\
\text { especially when he gives out case studies for the students to make connections with. His students responded very } \\
\text { well to his style of teaching." }\end{array}$ \\
\hline $\mathrm{SCH} 3 \mathrm{U}$ & $\begin{array}{l}\text { "Had a guided inquiry activity at the beginning of the lesson, where she gave each student math building blocks } \\
\text { and a situation regarding owning a building business but having a limited amount of blocks to build with. She } \\
\text { introduced limiting reagents after students explored the situation." } \\
\text { "I found that this lesson was more problem-based. She facilitated most learning. The class was very interactive, } \\
\text { and students used a lot of scaffolding." }\end{array}$ \\
\hline SBI4U & $\begin{array}{l}\text { "This teacher had a flipped classroom. Students were very engaged and had more questions because they had a } \\
\text { chance to process the information the night before." } \\
\text { "He related the process of making DNA to obtaining someone's recipe and recreating it. The recipe must come } \\
\text { from the source if you want to recreate it. Students understood this concept and we able to relate it to the topic." } \\
\text { "He used small steps and didn't move forward until everyone understood." } \\
\text { "Students practiced making their own RNA strands, exploring how the mechanism worked." }\end{array}$ \\
\hline
\end{tabular}

Table 6. Chinese teacher candidate reflections

\begin{tabular}{|c|c|}
\hline $\begin{array}{c}\text { Teacher } \\
\text { Participant }\end{array}$ & Chinese Teacher Candidate Researchers' Reflections \\
\hline Chemistry, Grade 11 & $\begin{array}{l}\text { "Teacher frequently guided students to participate in the teaching activities and design experimental plans." } \\
\text { "The questions put forward by teachers reached the level of analysis. Students were required to apply knowledge } \\
\text { and skills in new situations." } \\
\text { "The teacher evaluated the students' response, and adjusted the teaching method based on the students' response." }\end{array}$ \\
\hline Biology, Grade 11 & $\begin{array}{l}\text { "This class is a new lesson about "environment of cell life". The teacher is the center of the class. In the course of } \\
\text { teaching, the emphasis and difficulty were outstanding, and the teachers could connect the old knowledge with the } \\
\text { new knowledge, but there were few inquiry activities, and the students were always passive learners." } \\
\text { "In the class, the teacher asked students some questions, but most of the questions have only one correct answer. } \\
\text { Some questions were open questions, and students only responded verbally." }\end{array}$ \\
\hline Chemistry, Grade 10 & $\begin{array}{l}\text { "This class focused on the chemical property of chlorine. Because there were so many knowledge points in this } \\
\text { class, the teacher explained the teaching contents through videos at most of time. However, the participation of } \\
\text { students was not enough." } \\
\text { "There were some questions asked by teacher in this class, but most of time she answered it. Because the teacher } \\
\text { rarely invited students to answer it or gave less time to students to think, and teacher mostly guided students to } \\
\text { answer questions. The content of chlorine water was inquired into, which required the students to put forward the } \\
\text { test reagent according to the possible substances, but the explore meaning of the whole class was not obvious." }\end{array}$ \\
\hline Physics, Grade 10 & $\begin{array}{c}\text { "The teacher as students' learning guide continuously and effectively, guided students to use previous knowledge } \\
\text { to solve the computational problem of the first cosmic velocity." } \\
\text { "Teacher can attracted students to participate in analysis, discussion and inquiries." } \\
\text { "Teachers guided students to participate in deliberation and discussion with some questions and pushed them } \\
\text { according to students' answers to encourage them to think more at a higher level." } \\
\text { "There are some inquiry activity in the curriculum. } \\
\text { Students also took notes to help them understand the point of knowledge." }\end{array}$ \\
\hline Biology, Grade 11 & $\begin{array}{l}\text { "In the whole class, teacher was the center of the class at most of time. After understanding the concept of } \\
\text { carcinogenic factors, students can explain how harmful carcinogenic factors are." } \\
\text { "The teacher asked some questions in class, but most of the questions have only one correct answer and some are } \\
\text { open issues. The questions asked by the teacher are at the students' level of understanding." } \\
\text { "The teacher evaluated the students' prior knowledge and the correctness and wrongness of the students' answer, } \\
\text { but only part of evaluations could attract students to reflect on the problems." }\end{array}$ \\
\hline
\end{tabular}




\begin{tabular}{|c|c|}
\hline $\begin{array}{c}\text { Teacher } \\
\text { Participant }\end{array}$ & Chinese Teacher Candidate Researchers' Reflections \\
\hline Physics, Grade 10 & $\begin{array}{l}\text { "Teacher is the center of the class. } \\
\text { She frequently taught in expository methods and occasionally guided students to study." } \\
\text { "In the class, the teacher's lecture took up the most time, and little time is left for students' discussion." } \\
\text { "In the progress of teaching, the teacher adjusted the way of teaching according to the students' feedback." } \\
\text { "The course provides a prescriptive inquiry approach to explore the relationship between the speed of planets in the } \\
\text { perihelion and aphelion. Students also make related records } \\
\text { when they understand what the teacher is talking about." }\end{array}$ \\
\hline
\end{tabular}

The Canadian teacher candidates predominantly observed problem-based learning, rather than inquiry-based learning. Most of the observed science lessons contained some type of lab or experiment that promoted discovery but was still guided and laid out in a step-by-step manner. Many teacher candidates reported that teachers used questioning effectively in order to engage their students. Scaffolding was used in a number of lessons and interactive activities were used in an effort to increase student engagement and excitement regarding the topic being presented in class.

The Chinese teacher candidates predominantly observed teacher-centred classrooms. The teacher-centred classrooms involved teachers asking questions, waiting for student responses, and adjusting the lessons accordingly. Based on the observations, it does not appear that many science classrooms within our Chinese sample are using inquiry-based teaching methods in their classrooms. Most teacher candidates observed there were numerous and constant connections to prior learning and that lesson were often very difficult and/or intellectually stimulating.

\section{Results \& Discussion}

To answer RQ1, we first analyzed data from sections iv-vii in the EQUIP assessment. Data suggests that three out of the six Canadian teacher participants displayed an overall 'proficient' level of inquiry. The other three displayed an overall level of 'developing' inquiry. Our small sample size is not large enough to generalize the level of IBT for the entire population of secondary science teachers in Ontario, and more largely Canada. However, it does provide some insight into the second part of RQ1: how our teachers are implementing IBT.

To answer the second part of RQ1, the time observations in section ii were analyzed observationally for frequent data that was facilitated by teachers. Data suggested that the three Canadian teacher participants with the lowest levels of inquiry (Table 1, Summative Overview) spent the most time on non-instructional tasks (administrative tasks, handing out/back papers, general announcements, and little instruction) and non-inquiry-based tasks (rote memorization, drill and practice, checking homework answers, classwork with no explanation, skill automation-based activities, and quizzes). The three
Canadian teacher participants with the highest levels of inquiry (Table 1, Summative Overview) spent the most time on engaging, student-centred, guided lessons that emphasized process and allowed students to explore before collaborating on an explanation.

To answer RQ2, the time observations in section ii were analyzed observationally for frequent data displayed by the students. Data suggested that the three Canadian teacher participants with the lowest levels of inquiry corresponded with students that had low-medium attention spans where some students were off task, disruptive, or demonstrated short-term receipt of the knowledge. The three Canadian teacher participants with the highest levels of inquiry corresponded with students that had medium-high attention spans where most students were attending to the lesson, volunteering ideas, answering questions, engaging, participating, and applying the knowledge for further analyzation.

To answer RQ3, similar to the findings of the Canadian teachers, the Chinese teachers did not incorporate true inquiry-based teaching. The Chinese teacher data showed three of the seven teachers appeared to be at a proficient level and the others were at a level of 'developing' inquiry. Once again, due to the small sample size the findings are not generalizable for Southwest China, and more largely, China. Most of the observers found the teachers using traditional questions based on knowledge answers rather than higher order responses that require metacognition. No teacher actually conducted an inquiry-based lesson. Inquiry is often mistaken for problem-based teaching where a problem is solved through a series of guided questions. For example, the Physics, Grade 10 was based more on lecture than discussion. The term "prescriptive inquiry" is used as a teaching strategy. It appears that prescriptive inquiry is a bit of an oxymoron in that prescriptive involves telling people what they should do, not really allowing for inquiry at all.

For both the Canadian and Chinese teachers, the reflections from the teacher candidate researchers were used for the validation of the quantitative EQUIP assessments. Despite the lack of significance based on the small sample size, this qualitative data provides further insight into the comprehension of IBT from both the teacher participants and furthermore, the teacher candidate researchers' perspectives.

Although the quantitative data showed that both the 
Canadian teachers and the Chinese teachers reached levels of proficiency in the use of IBT, the qualitative data tells a different story. The observational responses of the teacher candidates after analyzing the videotapes stated teachers were not proficient in IBT. The classrooms were still teacher-centred and the questions were still surface knowledge-based questions. There was little evidence of critical thinking involved in any of the classes.

\section{Conclusions}

\section{Findings \& Implications}

We found that in secondary science classrooms, when teachers allowed students to explore concepts before explanations and contribute to the explanations, students participated more frequently at a higher cognitive level. This is further supported by Marshall, et al., 2009; 2011.

Furthermore, in the Canadian science teachers' lessons we have reviewed, it was apparent that not all teachers utilize inquiry-based teaching proficiently. It seems that not all teachers are proficient in IBT, which is counterproductive to Ontario's Ministry of Education standards (Ministry of Education, 2011). Although some Canadian teachers appear to be incorporating inquiry-based teaching, some Canadian teachers are not executing inquiry-based teaching that can be assessed by EQUIP. There were similar findings with the science teachers from China. Although they believe that what they are doing is inquiry, it is still very teacher-centred and autocratic in approach. The questions do not offer choice or voice and the responses are knowledge based rather than inquiry-based or even problem-based. Is the lack of inquiry-based teaching an effect of a misconception of what inquiry-based teaching involves? Or is it a fault in EQUIP? A larger sample size, and a different population will provide some clarity.

\section{Limitations \& Challenges}

There are several limitations to this study. Firstly, there is a lack in sample size for generalizability. Of the 6 teacher participants, only 3 secondary schools were represented out of the 10 GECDSB secondary schools. This sample size is not representative of the entire Canadian population of secondary school teachers, and therefore, we cannot generalize these results. Furthermore, the EQUIP assessment tool required a sample size of 16 participants in order to be reliable and valid, however, the qualitative observational annotations provide support for the data on a smaller scale.

Another limitation lies in teacher performance under the knowledge of being recorded. Did teachers improve their performance for their audience? Teachers may have been hyperaware of their teaching and could have increased their performance for their teacher candidate research spectator. This poses the issue of whether video recording is a true demonstration of their inquiry-based teaching. These video recordings were on daily lessons and inquiry requires a very structured approach for student led inquiry. 


\section{Appendix}

\section{EQUIP}

\section{EQUIP}

(Electronic Quality of Inquiry Protocol)

Complete Sections I before and during observation, Sections II and III during the observation, and Sections IV-VII immediately after the observation. If a construct in Sections IV-VI absolutely cannot be coded based on the observation, then it is to be left blank.

Observation dalo:

Tine start:

Tine end:

Obscrver:

School: District: Teacher:

Course

\section{Descriptive Information}

\section{A. Teacher Descriptive Information:}

1. Teacher gender Male (M), Temale ( $\Gamma)$

2. Teacher ethnicity Caucasian (C), $\Lambda$ frican- $A$ merican $(\Lambda)$, Latimo (L), Other $(O)$

3. Grade level(s) observed 4. Subject/Course observed

5. Highest degree 6. Number of years experience: 7. Number of years teaching this content

\section{B. Student/Class Descriptive Information}

1. Number of students in class:

2. Gender distribution: Males Females

3. Ethmicity distribution Caucasian (C) African-American (A) Latino (L) Other

\section{Lesson Descriptive Information}

1. Is the lesson an exemplar that follows the 4E $\mathrm{x} 2$ Instructional Model? (PDI exemplar, non-PDI exemplar, non-exemplar)

2. Working title for lesson:

3. Objectives/Purpose ol' lesson: Inlened (I), Explicil (E)

4. Standards addressed: State (S), District (D), None Fxplicit (N)

\begin{tabular}{|c|c|c|c|c|c|c|}
\hline \multicolumn{7}{|c|}{ II. Time Usage Analysis } \\
\hline Time & Activity Codes & Organization Codes & $\begin{array}{l}\text { Student Attention to } \\
\text { Lesson Codes }\end{array}$ & Cognitive Codes & $\begin{array}{l}\text { Inquiry Instruction } \\
\text { Component Codes }\end{array}$ & $\begin{array}{c}\text { Assessment } \\
\text { Codes }\end{array}$ \\
\hline \multicolumn{7}{|l|}{$0-5$} \\
\hline \multicolumn{7}{|l|}{$5-10$} \\
\hline \multirow{2}{*}{\multicolumn{7}{|c|}{$\begin{array}{l}10-15 \\
15-20\end{array}$}} \\
\hline & & & & & & \\
\hline \multicolumn{7}{|l|}{$20-25$} \\
\hline \multicolumn{7}{|c|}{$25-30$} \\
\hline \multirow{2}{*}{\multicolumn{7}{|c|}{$\begin{array}{l}30-35 \\
35-40\end{array}$}} \\
\hline & & & & & & \\
\hline \multicolumn{7}{|l|}{$40-45$} \\
\hline \multicolumn{7}{|c|}{$45-50$} \\
\hline \multirow{2}{*}{\multicolumn{7}{|c|}{$\begin{array}{l}50-55 \\
55-60\end{array}$}} \\
\hline & & & & & & \\
\hline \multicolumn{7}{|l|}{$60-65$} \\
\hline \multirow{2}{*}{\multicolumn{7}{|c|}{$\begin{array}{l}65-70 \\
70-75\end{array}$}} \\
\hline & & & & & & \\
\hline \multicolumn{7}{|c|}{$75-80$} \\
\hline \multicolumn{7}{|c|}{$80-85$} \\
\hline $85-90$ & & & & & & \\
\hline
\end{tabular}


Acrivity Codes-facilitated by teacher

0 . Non-instructional time - administrative tasks, handing backicollecting papers, general announcements, time away from instnection

1. Prc-inquiry teacher-centered, passive students, prescriptive, didactic discourse pattem, no inquiry attempted

2. Dcveloping inquiry teacher-centered with some active engagement of students, prescriptive though not entirely, mostly didactic with some open-ended disenssions, leacher dominales the explain. Ieacher seen as both giver of knowledes and as a facilitator. begimining of elass wamn-ulus

3. Proflcient inquiry-largely student-centered, focus on students as active learners, inquiries are guided and include student input, discourse includes discussions that emphasize process as much as product, teacher facilitates learning and students active in all stages, including the explain phase

4. Excmplary inquiry student-centered, students active in constructing understanding of content, rich teacher-student and student-student dialogue, teacher facilitates learning in effective ways to encourage student learning and conecptual development, assumptions and misconceptions are ehallenged by students and leacher

Organization Codes-led by teacher

W Whole class

S Small group

I Individual work

Student Attention to Lesson Code-displayed by students

L Low attention, $20 \%$ or fewer attending to the lesson. Most students are off-task - heads on desks, staring out of the window, chatting with neighbors, etc

M Medium attention, between $20-80 \%$ of students are attending to the lesson.

$\mathrm{H}$ High attcntion, $80 \%$ or more of the students are attending to the lesson. Most students are taking notes or looking at the teacher during lecture, writing on the workshect, most students are voluntecring ideas during a discussion, most students are engaged in small group diseussions even without the presence of the teacher.

Cognitive Code-dispiayed by students

0 . Other-e g. classroom disruption, non-instructional portion of lesson, administrative activity

1. Receipt of knowledge

2. I ower order (recall, remember, understand) and/or activitics foeused on completion exereises, computation

3. Apply (demonstrate, modify, compare) and/or activities focused on problem solving

1. Analyze/Tvaluate (evidence, verify, analyze, justify, interprel)

5. Create (combine, construct, develop, formulate)

Inquiry Instructional Component Code-facilitated by teacher

0. Non-inquiry: activities with the purpose of skill automation; rote memorization of facts; drill and practice; checking answers on homework, quizzes, or classwork with little or no explanation

1. Engage: typically situated at the begiming of the lesson: assessing student prior knowledge and misconceptions; stimulating student interest

2. Explore: students investigate a new idea or concept

3. Explain: teacher or students making sense of an idea or concept Extend: [Fxtend is important but is not coded as such because it typically is a new Fngage, Fxplore, or Fxplain]

Assessment Code-facilitated by teacher

0. No assessment observed

1. Monitoring (circulating around the room, probing for understanding, checking student progress, commenting as appropriate)

2. Formative assessment (assessing student progress, instruction modified to align with student ability) or Diagnostic assessment (checking for prior knowledge, misconceptions, abilitics)

3. Summative assessment (assessing student leaming, evaluative and not informing next instructional step)

\begin{tabular}{|c|c|c|}
\hline \multicolumn{2}{|c|}{ III. Lesson Descriptive Details } \\
\hline $\begin{array}{c}\text { Time (mins } \\
\text { into class) }\end{array}$ & Classroom Notes of Observation & Comments \\
\hline & & \\
\hline & & \\
\hline & & \\
\hline & & \\
\hline
\end{tabular}

\begin{tabular}{|c|c|c|c|c|c|}
\hline \multicolumn{6}{|c|}{ IV. Instructional Factors } \\
\hline \multicolumn{2}{|c|}{ Construct Measured } & Pre-Inquiry (Level 1) & Developing Inquiry (2) & Proficient Inquiry (3) & Exemplary Inquiry (4) \\
\hline I1. & $\begin{array}{l}\text { Instructional } \\
\text { Strategies }\end{array}$ & $\begin{array}{l}\text { Teacher predominantly } \\
\text { lectured to cover content. }\end{array}$ & $\begin{array}{l}\text { Teacher frequently lectured } \\
\text { and/or used demonstrations to } \\
\text { explain content. Activities } \\
\text { were verification only. }\end{array}$ & $\begin{array}{l}\text { l'cacher occasionally } \\
\text { lectured, but students were } \\
\text { engaged in activities that } \\
\text { helped develop conceptual } \\
\text { understanding. }\end{array}$ & $\begin{array}{l}\text { Teacher occasionally lectured, but } \\
\text { students were engaged in investigations } \\
\text { that promoted strong conceptual } \\
\text { understanding. }\end{array}$ \\
\hline $\mathrm{I} 2$. & $\begin{array}{l}\text { Order of } \\
\text { Instruction }\end{array}$ & $\begin{array}{l}\text { Teacher explained concepts. } \\
\text { Students eilher did not } \\
\text { explore concepts or did so } \\
\text { only afler explanation. } \\
\text { Teacher was center of } \\
\text { lesson; rarely acted as } \\
\text { facilitator. }\end{array}$ & $\begin{array}{l}\text { Teacher asked students to } \\
\text { explore concept before } \\
\text { receiving explanation. } \\
\text { Teacher explained. } \\
\text { Teacher was center of } \\
\text { lesson; occasionally acted as } \\
\text { facilitator. }\end{array}$ & $\begin{array}{l}\text { Teacher asked students to } \\
\text { explore before explanation. } \\
\text { Teacher and students } \\
\text { explained. } \\
\text { Teacher frequently acted as } \\
\text { facilitator. }\end{array}$ & $\begin{array}{l}\text { Teacher asked students to explore concept } \\
\text { before explantation occured. Though } \\
\text { perhaps prompled by the teacher, } \\
\text { students provided the explanation. } \\
\text { Teacher consistently and effectively } \\
\text { acted as a facilitator. }\end{array}$ \\
\hline I4. & Student Role & $\begin{array}{l}\text { Students were consistently } \\
\text { passive as learners (taking } \\
\text { notes, practicing on their } \\
\text { own). }\end{array}$ & $\begin{array}{l}\text { Students were active to a } \\
\text { small extent as lcarners } \\
\text { (highly engaged for very bricf } \\
\text { moments or to a small extent } \\
\text { thronghout lesson). }\end{array}$ & $\begin{array}{l}\text { Students were active as } \\
\text { learners (involved in } \\
\text { discussions, investigations, or } \\
\text { activities, but not consistently } \\
\text { and clearly focused). }\end{array}$ & $\begin{array}{l}\text { Studenls were consistently and } \\
\text { effectively active as learners (highly } \\
\text { engaged at multiple points during lesson } \\
\text { and clearly focused on the task). }\end{array}$ \\
\hline I5. & $\begin{array}{l}\text { Knowledge } \\
\text { Acquisition }\end{array}$ & $\begin{array}{l}\text { Student learning focused } \\
\text { solely on mastery of facts, } \\
\text { infonmation, and/or rote } \\
\text { processes. }\end{array}$ & $\begin{array}{l}\text { Student learning focissed on } \\
\text { mastery of facts and process } \\
\text { skills without much focus on } \\
\text { understanding of content. }\end{array}$ & $\begin{array}{l}\text { Student learning required } \\
\text { application of concepts and } \\
\text { process skills in new } \\
\text { siluations. }\end{array}$ & $\begin{array}{l}\text { Student learning required depth of } \\
\text { understanding to be demonstrated } \\
\text { rclating to content and process skills. }\end{array}$ \\
\hline
\end{tabular}




\section{Discourse Factors}

\begin{tabular}{|c|c|c|c|c|c|}
\hline \multicolumn{6}{|c|}{ V. Discourse Factors } \\
\hline \multicolumn{2}{|c|}{ Construct Measured } & Pre-Inquiry (Level 1) & Developing Inquiry (2) & Proficient Inquiry (3) & Exemplary Inquiry (4) \\
\hline D1. & $\begin{array}{l}\text { Qucstioning } \\
\text { Level }\end{array}$ & $\begin{array}{l}\text { Questioning rarely } \\
\text { challenged students above } \\
\text { the remembering level. }\end{array}$ & $\begin{array}{l}\text { Questioning rarely challenged } \\
\text { students above the } \\
\text { understanding level. }\end{array}$ & $\begin{array}{l}\text { Questioning challenged } \\
\text { students up to application or } \\
\text { analysis levels }\end{array}$ & $\begin{array}{l}\text { Questioning challenged students at } \\
\text { various levels, including at the analysis } \\
\text { level or higher; level was varied to } \\
\text { scaffold learning. }\end{array}$ \\
\hline D2. & $\begin{array}{l}\text { Complexity of } \\
\text { Questions }\end{array}$ & $\begin{array}{l}\text { Questions focused on one } \\
\text { corrcct answer; typically } \\
\text { shurt answer responses. }\end{array}$ & $\begin{array}{l}\text { Questions focused mostly on } \\
\text { one correct answer; some } \\
\text { openl response opportunities. }\end{array}$ & $\begin{array}{l}\text { Questions challenged } \\
\text { students to explain, reason, } \\
\text { and/or justify. }\end{array}$ & $\begin{array}{l}\text { Questions required students to explain, } \\
\text { rcason, and/or justify. Students were } \\
\text { expected to critique others' responses. }\end{array}$ \\
\hline D3. & $\begin{array}{l}\text { Questioning } \\
\text { Ecology }\end{array}$ & $\begin{array}{l}\text { Teacher lectured or engaged } \\
\text { students in oral questioning } \\
\text { that did not lead to } \\
\text { discussion. }\end{array}$ & $\begin{array}{l}\text { Teacher occasionally } \\
\text { attempted to engage } \\
\text { students in discussions or } \\
\text { investigations but was not } \\
\text { successful. }\end{array}$ & $\begin{array}{l}\text { Teacher successfully engaged } \\
\text { students in open-ended } \\
\text { questions, discussions, and/or } \\
\text { investigations. }\end{array}$ & $\begin{array}{l}\text { Teacher consistently and effectively } \\
\text { engaged students in open-ended } \\
\text { questions, discussions, investigations, } \\
\text { and/or reflections. }\end{array}$ \\
\hline D4. & $\begin{array}{c}\text { Communication } \\
\text { Pattern }\end{array}$ & $\begin{array}{l}\text { Communication was } \\
\text { controlled and directed by } \\
\text { teacher and followed a } \\
\text { didactic pattem. }\end{array}$ & $\begin{array}{l}\text { Cummunication was typically } \\
\text { controlled and dirceted by } \\
\text { teacher with occasional input } \\
\text { from other students; mostly } \\
\text { didactic pattern. }\end{array}$ & $\begin{array}{l}\text { Communication was often } \\
\text { conversational with some } \\
\text { student qliestions gniding the } \\
\text { discussion. }\end{array}$ & $\begin{array}{l}\text { Communication was consistently } \\
\text { conversational with student questions } \\
\text { often guiding the discussion. }\end{array}$ \\
\hline D5. & $\begin{array}{l}\text { Classroom } \\
\text { Interactions }\end{array}$ & $\begin{array}{l}\text { Teacher accepted answers, } \\
\text { corrccting when necessary, } \\
\text { but rarely followed-up wilh } \\
\text { further probing. }\end{array}$ & $\begin{array}{l}\text { Teacher or another student } \\
\text { occasionally followed-up } \\
\text { student response with further } \\
\text { low-levcl probc. }\end{array}$ & $\begin{array}{l}\text { Teacher or another student } \\
\text { often followed-up response } \\
\text { with engaging probe that } \\
\text { required student to justify } \\
\text { reasoning or evidence. }\end{array}$ & $\begin{array}{l}\text { Teacher consistently and effectively } \\
\text { facilitated rich classroom dialogue } \\
\text { where evidence, assumptions, and } \\
\text { reasoning were challenged by teacher or } \\
\text { other students. }\end{array}$ \\
\hline
\end{tabular}

\begin{tabular}{|c|c|c|c|c|c|}
\hline \multicolumn{6}{|c|}{ VI. Assessment Factors } \\
\hline \multicolumn{2}{|c|}{ Construcl Measured } & \multirow{2}{*}{$\begin{array}{l}\text { Pre-Inquiry (Level 1) } \\
\text { Teacher did not assess } \\
\text { student prior knowledge. }\end{array}$} & \multirow{2}{*}{$\begin{array}{l}\text { Developing Inquiry (2) } \\
\text { Teacher assessed student } \\
\text { prior knowledge but did not } \\
\text { modify instruction based on } \\
\text { this knowledge. }\end{array}$} & \multirow{2}{*}{$\begin{array}{l}\text { Proficient Inquiry (3) } \\
\text { Teacher assessed student prior } \\
\text { knowledge and then partially } \\
\text { modified instruction based } \\
\text { on this knowledge. }\end{array}$} & \multirow{2}{*}{$\begin{array}{l}\text { Exemplary Inquiry (4) } \\
\text { Teacher assessed student prior knowledge } \\
\text { and then modified instruction bascd on } \\
\text { this knowledge. }\end{array}$} \\
\hline Al. & $\begin{array}{c}\text { Prior } \\
\text { Knowledge }\end{array}$ & & & & \\
\hline A2. & $\begin{array}{c}\text { Conceptual } \\
\text { Development }\end{array}$ & $\begin{array}{l}\text { Teacher encouraged learning } \\
\text { by memorization and } \\
\text { repetition. }\end{array}$ & $\begin{array}{l}\text { Teacher encouraged product- } \\
\text { or answer-focused learning } \\
\text { activitics that lacked critical } \\
\text { thinking. }\end{array}$ & $\begin{array}{l}\text { Teacher encouraged process- } \\
\text { focused learning activities } \\
\text { that required critical } \\
\text { thinking. }\end{array}$ & $\begin{array}{l}\text { used } \\
\text { critical } \\
\text { ng with }\end{array}$ \\
\hline A3. & $\begin{array}{c}\text { Student } \\
\text { Reflection }\end{array}$ & $\begin{array}{l}\text { Teacher did not explicitly } \\
\text { encourage students to reflect } \\
\text { on their own learning. }\end{array}$ & $\begin{array}{l}\text { Teacher explicitly en } \\
\text { students to reflect on } \\
\text { learning but only at a } \\
\text { knowledge level. }\end{array}$ & $\begin{array}{l}\text { encouraged } \\
\text { on their } \\
\text { erstanding }\end{array}$ & $\begin{array}{l}\text { Teacher consistently encouraged students } \\
\text { to reflect on their learning at multiple } \\
\text { times throughout the lesson; encouraged } \\
\text { students to think at higher levels. }\end{array}$ \\
\hline A4. & $\begin{array}{l}\text { Assessment } \\
\text { Type }\end{array}$ & $\begin{array}{l}\text { Formal and informal } \\
\text { assessments measured only } \\
\text { factual, discrete knowledge. }\end{array}$ & $\begin{array}{l}\text { Formal and informal } \\
\text { assessments measured } \\
\text { mostly factual, discrete } \\
\text { knowledge. }\end{array}$ & $\begin{array}{l}\text { Formal and informal } \\
\text { assessments used both } \\
\text { factual, discrete knowledge } \\
\text { and authentic measures. }\end{array}$ & $\begin{array}{l}\text { Formal and informal assessment methods } \\
\text { consistently and effectively used } \\
\text { authentic measures. }\end{array}$ \\
\hline A5. & $\begin{array}{c}\text { Role of } \\
\text { Assessing }\end{array}$ & $\begin{array}{l}\text { Teacher solicited } \\
\text { predetermined answers from } \\
\text { students requiring little } \\
\text { explanation or justification. }\end{array}$ & $\begin{array}{l}\text { Teacher solicited } \\
\text { information from students } \\
\text { to assess understanding. }\end{array}$ & $\begin{array}{l}\text { Tcacher solicited explanations } \\
\text { from students to assess } \\
\text { understanding and then } \\
\text { adjusted instruction } \\
\text { accordingly. }\end{array}$ & $\begin{array}{l}\text { Tcacher frequently and cffcctivcly } \\
\text { assessed student understanding and } \\
\text { adjusted instruction accordingly; } \\
\text { challenged evidence and claims made; } \\
\text { encouraged curiosity and openness. }\end{array}$ \\
\hline
\end{tabular}

\begin{tabular}{|l|l|l|l|l|l|}
\hline \multicolumn{2}{|c|}{ VII. Curriculum Factors } \\
\hline Construct Measured & \multicolumn{1}{|c|}{ Pre-Inquiry (Level 1) } & \multicolumn{1}{|c|}{ Developing Inquiry (2) } & \multicolumn{1}{|c|}{ Proficient Inquiry (3) } & \multicolumn{1}{|c|}{ Exemplary Inquiry (4) } \\
\hline C1. & Content Depth & $\begin{array}{l}\text { Lesson provided only } \\
\text { superficial coverage of } \\
\text { content. }\end{array}$ & $\begin{array}{l}\text { Lesson provided some depth } \\
\text { of content but with no } \\
\text { connections made to the big } \\
\text { picture. }\end{array}$ & $\begin{array}{l}\text { Lesson provided depth of } \\
\text { content with some significant } \\
\text { connection to the big picture. }\end{array}$ & $\begin{array}{l}\text { Lesson provided depth of content with } \\
\text { significant, clear, and explicit } \\
\text { connections made to the big picture. }\end{array}$ \\
\hline C2. & $\begin{array}{l}\text { Learner } \\
\text { Centrality }\end{array}$ & $\begin{array}{l}\text { Lesson did not engage } \\
\text { learner in activities or } \\
\text { investigations. }\end{array}$ & $\begin{array}{l}\text { Lesson provided prescribed } \\
\text { activities with anticipated } \\
\text { results. }\end{array}$ & $\begin{array}{l}\text { Lesson allowed for some } \\
\text { flexibility during } \\
\text { investigation for student- } \\
\text { designed exploration. }\end{array}$ & $\begin{array}{l}\text { Lesson provided flexibility for students } \\
\text { to design and carry out their own } \\
\text { investigations. }\end{array}$ \\
\hline C3. & $\begin{array}{c}\text { Integration of } \\
\text { Content and } \\
\text { Investigation }\end{array}$ & $\begin{array}{l}\text { Lesson either content- } \\
\text { focused or activity-focused } \\
\text { but not both. }\end{array}$ & $\begin{array}{l}\text { Lesson provided poor } \\
\text { integration of content with } \\
\text { activity or investigation. }\end{array}$ & $\begin{array}{l}\text { Lesson incorporated student } \\
\text { investigation that linked well } \\
\text { with content. }\end{array}$ & $\begin{array}{l}\text { Lesson seamlessly integrated the } \\
\text { content and the student investigation. }\end{array}$ \\
\hline C4. & $\begin{array}{c}\text { Organizing \& } \\
\text { Recording } \\
\text { Information }\end{array}$ & $\begin{array}{l}\text { Students organized and } \\
\text { recorded information in } \\
\text { prescriptive ways. }\end{array}$ & $\begin{array}{l}\text { Students had only minor } \\
\text { input as to how to organize } \\
\text { and record information. }\end{array}$ & $\begin{array}{l}\text { Students regularly organized } \\
\text { and recorded information in } \\
\text { non-prescriptive ways. }\end{array}$ & $\begin{array}{l}\text { Students organized and recorded } \\
\text { information in non-prescriptive ways that } \\
\text { allowed them to effectively communicate } \\
\text { their learning. }\end{array}$ \\
\hline
\end{tabular}




\begin{tabular}{|l|l|}
\hline \multicolumn{1}{|c|}{ VIII. Summative Overviews* } & $\begin{array}{c}\text { Comprehensive } \\
\text { Score*** }\end{array}$ \\
\hline $\begin{array}{c}\text { Summative } \\
\text { view of } \\
\text { Instruction } \\
\text { Summative } \\
\text { view of } \\
\text { Discourse }\end{array}$ & \\
\hline $\begin{array}{c}\text { Summative } \\
\text { view of } \\
\text { Asscssmcnt }\end{array}$ & \\
\hline $\begin{array}{c}\text { Summative } \\
\text { view of } \\
\text { Curriculum }\end{array}$ & \\
\hline $\begin{array}{l}\text { Overall vicw } \\
\text { of Lesson }\end{array}$ & \\
\hline
\end{tabular}

*Provide brief descriptive comments to justify score.

** Seore for each component should be an integer from 1-4 that corresponds with the appropriate level of inquiry. Scores should reflect the essence of the lesson relative to that component, so they need not be an exact average of all sub-scores in a category.

Marshall, J. C., Horton, B., Smart, J., \& T.lewellyn, D. (2008). E.UIP. Flectronic Quality of Inquiry Protocol: Retrieved from Clemson University's Inquiry in Motion Institute, www.clemson.cdiviim.

Inquiry in Motion (2009). All rights reserved. Marshall, J., Horton, B., Smart, J., \& Llewellyn, D. (2009) EQUIP: Electronic Quality of Inquiry Protocol. Retrieved from Clemson University's Inquiry in Motion Institute, www.clemson.edu/iim

\section{REFERENCES}

[1] Blackwell, L., Trzesniewski K., \& Dweck, C. (2007). Implicit theories of intelligence predict achievement across an adolescent transition: A longitudinal study and an intervention. Child Development, 78(1), 246-263.

[2] Bodzin \& Beerer. (2003). Promoting inquiry-based science instruction: The validation of the Science Teacher Inquiry Rubric (STIR). Journal of Elementary Science Education, 15(2), 39-49.

[3] Bransford, J. D., Brown, A. L., \& Cocking, R. R. (2000). How people learn: Brain, mind, experience, and school (expanded ed.). Washington, DC: National Academies Press.

[4] Buss, R. (2010). Efficacy for teaching elementary science and mathematics compared to other content. School Science and Mathematics, 110(6), 290-297.
[5] Cleary, T., Callan, G., Malatesta, J. \& Adams, T. (2015). Examining the level of convergence among self-regulated learning microanalytic processes, achievement, and a self-report questionnaire. Journal of Pyschoeducational Assessment, 33(5), 439-450.

[6] Creswell, J. W. \& Clark, V. L. P. (2007). Designing and conducting mixed methods research. SAGE Publications.

[7] Dewey, J. (1916). Democracy and education: An introduction to the philosophy of education. New York, NY: Macmillan.

[8] Furtak, E. M., Seidel, T., Iverson, H., \& Briggs, D. C. (2012). Experimental and quasi-experimental studies of inquiry-based science teaching: A meta-analysis. Review of educational research, 82(3), 300-329.

[9] Giddings, L. (2005). Factors influencing teaching style in block-scheduled science classrooms. Doctoral dissertation. Hofstra University.

[10] Hamzeh, F. (2014). Lesson study-building communities of learning among pre-service science teachers. Master's dissertation. University of Windsor, \#1562240.

[11] Howitt, C. (2007). Pre-service elementary teachers' perceptions of factors in a holistic methods course influencing their confidence in teaching science. Research in Science Education, 37(1), 44-58. 
[12] Jang, H., Reeve, J., \& Deci, E. (2010). Engaging students in learning activities: It is not autonomy support or structure but autonomy support and structure. Journal of Educational Psychology, 10(3), 588-600.

[13] Llewellyn, D. (2002). Inquiry within: Implementing inquiry-based science standards. Thousand Oaks, CA: Corwin Press.

[14] Marshall, J. (2009). The creation, validation, and reliability associated with the EQUIP (Electronic Quality of Inquiry Protocol): A measure of inquiry-based instruction. Paper presented at the National Association of Researchers of Science Teaching Conference.

[15] Marshall, J., Horton, B., Igo, B., \& Sqitzer, D. (2009). K-12 science and mathematics teachers' beliefs about use of inquiry in the classroom. International Journal of Science and Mathematics Education, 7(3), 575-596.

[16] Marshall, J., Horton, B., \& Smart, J. (2008). 4Ex2 Instructional Model: Uniting three learning constructs to improve praxis in science and mathematics classrooms. Journal of Science Techer Education. Retrieved from: http://media.clemson.edu/education/iim/documents/4ex2-js te-article.pdf

[17] Marshall \& Horton. (2011). The relationship of teacher-facilitated inquiry-based instruction to student higher-order thinking. School Science and Mathematics, 111(3), 93-101.

[18] Ministry of Education. (2011). Capacity Building Series: Getting Started with Student Inquiry. Retrieved from: http://www.edu.gov.on.ca/eng/literacynumeracy/inspire/res earch/CBS_StudentInquiry.pdf

[19] Ministry of Education. (2013). School Effectiveness Framework: A support for school improvement and student success. Retrieved from: http://www.edu.gov.on.ca/eng/llit eracynumeracy/SEF2013.pdf

[20] National Research Council. (1996). National science education standards. Washington, DC: National Academies Press.

[21] National Research Council. (2000). Inquiry and the national science education standards: A guide for teaching and learning. Washington, DC: National Academies Press.
[22] Nenneman, P. (1971). Factors influencing teaching methods of first, second, and third year Nebraska University graduates in the teaching of elementary school social science. University of Nebraska.

[23] Pajares, F. (2005). Self-efficacy during childhood and adolescence: Implications for teachers and parents. Information Age Publishing, 339-367.

[24] PISA. (2015). PISA results in focus. Retrieved from: https://www.oecd.org/pisa/pisa-2015-results-in-focus.pdf

[25] Posnanski, T. (2002). Professional development programs for elementary science teachers: An analysis of teacher self-efficacy beliefs and a professional development model. Journal of Science Teacher Education, 13(2), 189-220.

[26] Riggs, I. \& Enochs, L. (1990). Toward the development of an elementary teacher's science teaching efficacy belief instrument. Science Education, 74(6), 625-637.

[27] Sanders, W., \& Rivers, J. (1996). Cumulative and residual effects of teachers on future student academic achievement (University of Tennessee Value-Added Research and Assessment Center). Retrieved from http://www.mccsc.edu/ curriculum/cumulative $\% 20$ and $\% 2$ Oresidual $\% 20$ effects $\% 20$ of $\% 20$ teachers.pdf

[28] Sawada, D., Piburn, M., Falconer, K. Turley, J., Benford, R., \& Bloom, I. (2000). Reformed Teaching Observation Protocol (RTOP) (Technical Report No. IN00-01): Arizona State University.

[29] Shrigley, R. \& Johnston, T. (1974). The attitude of in-service elementary teacher toward science. Science School and Mathematics, 74(5), 437-446.

[30] TIMSS. (2015) Science student achievement. Retrieved from: http://timss2015.org/timss-2015/science/student-achievem ent/

[31] Tomlinson, C. A., \& McTighe, J. (2003). Integrating differentiated instruction and understanding by design. Alexandria, VA: Association for Supervision and Curriculum Development.

[32] Vygotsky, L. (1962). Thought and language. Cambridge, MA: MIT Press. 